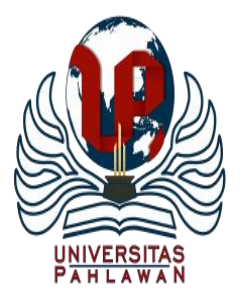

Jurnal Abdidas Volume 1 Nomor 5 Tahun 2020 Halaman 373 - 378

JURNAL ABDIDAS

Community Development Service on Educational and Health Sciences

http://abdidas.org/index.php/abdidas

\title{
Pelatihan Pemanfaatan Google Classroom untuk Mendukung Kegiatan Pembelajaran Daring saat Pandemi COVID 19 di SMPIT Insan Rabbani
}

\author{
Diah Aryani $^{1}$, Malabay ${ }^{2}$, Hani Dewi Ariessanti ${ }^{3}$, Syahrizal Dwi Putra ${ }^{4}$ \\ Universitas Esa Unggul, DKI Jakarta, Indonesia ${ }^{1,2,3,4}$ \\ E-mail : diah.aryani@esaunggul.ac.id ${ }^{1}$ malabay@esaunggul.ac.id ${ }^{2}$ hani.dewi@esaunggul.ac.id ${ }^{3}$ \\ syahrizal.dwi@esaunggul.ac.id ${ }^{4}$
}

\begin{abstract}
Abstrak
SMPIT Insan Rabbani juga berperan serta untuk menjaga keberlangsungan pembelajaran tetap berjalan dengan baik selama masa pandemi mengikuti Surat Edaran Nomor 15 Tahun 2020 tentang Pedoman Penyelenggaraan Belajar Dari Rumah Dalam Masa Darurat Penyebaran COVID-19. Melalui kegiatan abdimas ini bertujuan untuk sharing knowledge terkait metode pembelajaran online yang saat ini sangat dibutuhkan pada masa pandemi dengan pemanfaatan media pembelajaran online sebagai pendukung peningkatan pelayanan pendidikan kepada guru memiliki kemampuan dalam pemanfaatan aplikasi Google Classroom. Semetara metode yang digunakan metode training secara praktis melalui transfer ilmu melalui pelatihan dan simulasi pelatihan aplikasi Google Classroom yang dilakukan secara virtual melalui Google Meets dan Zoom diharapkan tercapainya kemampuan yang merata dalam pemahaman dan penguasaan aplikasi Google Classroom sebagai pendukung pembelajaran online guna meningkatkan dan menambah pengetahuan dan kemampuan para guru dalam pemanfataan aplikasi Google Classroom sehingga kegiatan pembelajaran online dapat berjalan efektif dengan kemudahan bagi para guru untuk dapat membuat kelas virtual yang meliputi pemberian materi, kuis, tugas dan forum diskusi dengan para siswa tanpa harus melakukan penginstalan aplikasi terlebih dahulu.
\end{abstract}

Kata kunci: google classroom, pembelajaran online, google meets

\begin{abstract}
SMPIT Insan Rabbani also took part in maintaining the continuity of learning to run well during this pandemic under Regulation Number 15 of 2020 concerning Guidelines for Organizing Learning from Home in an Emergency for the Spread of Covid-19. This activity's objective is to share knowledge related to online learning methods, which are currently very much needed during the pandemic by using online learning media to support the improvement of educational services to teachers who can use the google classroom application. The method used is the practical training method to transfer knowledge and direct practice to the google classroom application virtually through google meets and zoom. It is hoped that equal ability can be achieved in understanding and mastery of the google classroom application to support online learning to improve and increase the knowledge and skills of teachers. In the use of the google classroom application so that online learning activities can run effectively with ease for teachers to create virtual classes, which include providing material, quizzes, assignments, and discussion forums with students without having to install the application first.
\end{abstract}

Keywords: google classroom, online learning, google meets

Copyright (c) 2020 Diah Aryani, Malabay, Hani Dewi Ariessanti, Syahrizal Dwi Putra

$\bowtie$ Corresponding author

Address : Fasilkom Univ.Esa Unggul

Email : diah.aryani@esaunggul.ac.id

ISSN 2721- 9224 (Media Cetak)

Phone : 082225969710

ISSN 2721- 9216 (Media Online)

DOI : https://doi.org/10.31004/abdidas.v1i5.67 
Pandemi COVID 19 di SMPIT Insan Rabbani - Diah Aryani, Malabay, Hani Dewi Ariessanti, Syahrizal Dwi Putra

DOI : https://doi.org/10.31004/abdidas.v1i5.67

\section{PENDAHULUAN}

Pandemi COVID-19 yang melanda Indonesia sejak bulan Maret 2020 sampai dengan saat ini sudah berdampak pada berbagai sektor termasuk pada dunia pendidikan sehingga dampak pandemi ini membuat dunia pendidikan harus melakukan transformasi dengan memanfaatkan teknologi informasi. Transformasi ini dilakukan guna mendukung pembelajaran yang mengharuskan proses kegiatan belajar mengajar tidak dilakukan di sekolah untuk sementara waktu guna memutus rantai penyebaran virus tersebut sehingga pemerintah mengambil kebijakan pembelajaran dilakukan melalui pembelajaran jarak jauh dengan media daring (dalam jaringan) dengan mempergunakan berbagai aplikasi media pembelajaran daring yang sudah tersedia seperti Ruang Guru, Google Classroom, Edmodo, Webex, VC Zoom, LMS Seamolec dan lain-lain. Aplikasi tersebut masing-masing memiliki kelebihan dan kekurangan tersendiri namun para guru dapat mempergunakan aplikasi yang sesuai dengan kemampuan dan kebutuhannya. Media daring secara umum merupakan segala jenis atau format media yang hanya bisa diakses melalui internet berisikan teks, foto, video dan suara, sebagai sarana komunikasi secara daring, sedangkan media daring merupakan sebuah platform yang memungkinkan penyebaran informasi tanpa halangan apapun seperti yang terjadi sebelumnya saat penyebaran informasi melalui media cetak (Rahmawati \& Anindhita, 2016).

Permasalahan yang ada saat ini adalah kurangnya pengetahuan dan kemampuan para guru SMPIT Insan Rabbani dalam penggunaan dan pemanfaatan berbagai aplikasi media pembelajaran daring, sehingga pada kegiatan ini bertujuan memberikan pelatihan dalam pemanfaatan salah satu aplikasi media pembelajaran yaitu layanan Google Classroom khususnya. Selain itu belum terbiasanya implementasi pembelajaran daring yang sudah berjalan beberapa pekan ini secara umum berjalan lancar. Kendati demikian, seiring perjalanan waktu sudah mencul banyak permasalahan. Di antaranya tugas guru yang terlalu banyak sampai keluhan soal kuota dan jaringan internet, maka dirumuskanlah bagaimana meningkatkan pengetahuan dan keterampilan para guru dalam menggunakan layanan-layanan aplikasi Google Classroom sebagai media pembelajaran daring guna mendukung kegiatan belajar mengajar.

Pada penelitian yang sudah dilakukan diharapkan memberi solusi terhadap metode yang selama ini diterapkan di kelas yaitu dengan metode konvensional dimana doses lebih mendominasi aktifitas pembelajaran baik dengan metode ceramah ataupun metode pemberian tugas (Sabran \& Sabara, 2019). Implementasi pembelajaran dengan Google Classroom lebih memudahkan dalam mengevaluasi keterlaksanaan proses belajar mengajar baik di kelas maupun di luar kelas. Pembelajaran dapat dikombinasikan antara metode konvensional dengan e-learning atau sering disebut Blanded Learning. Sehingga pada abdimas ini melanjutkan pelatihan kepada para guru agar memiliki pengetahuan dan kemampuan dalam penggunaan layanan Google Classroom dengan menggunakan berbagai media yang dapat diakses melalui internet seperti teks, video dan suara serta 
Pandemi COVID 19 di SMPIT Insan Rabbani - Diah Aryani, Malabay, Hani Dewi Ariessanti, Syahrizal Dwi Putra

DOI : https://doi.org/10.31004/abdidas.v1i5.67

memahami penggunaan fasilitas layanan Google lainnya seperti layanan Google Classroom yang untuk para guru dan siswa dapat melakukan penyimpanan data-data para guru dan siswa dengan menggunaan layanan penyimpanan Google Drive.

Saat ini Google Drive merupakan salah satu layanan penyimpanan yang banyak digunakan. Sehingga melalui pelatihan pemanfaatan Google Classroom ini diharapkan dapat terjadi transfer knowledge kepada guru-guru serta membantu pihak SMPIT Insan Rabanni dalam pengelolaan pembelajaran daring selama pandemi COVID 19 dengan baik dan lancar. Penggunaan Google Classroom ini sesungguhnya mempermudah guru dalam mengelola pembelajaran dan menyampaikan informasi secara tepat dan akurat terhadap siswa (Maharani \& Kartini, 2019).

\section{METODE}

Pelaksanaan kegiatan pengabdian kepada masyarakat yang dilaksanakan sebagai upaya memberikan solusi media pembelajaran yang akan dipergunakan pada pembelajaran daring selama masa pandemi ini adalah berbentuk kegiatan pelatihan pemanfaatan layanan Google Clasroom sebagai salah satu media pembelajaran pendukung pembelajaran daring pada dunia pendidikan dengan tahapan antara lain; pendaftaran peserta, pelatihan dan simulasi pelatihan yang disertai dengan penugasan.

\section{Pendaftaran peserta}

Pendaftaran peserta pelatihan abdimas ini diberikan melalui email dan Whatsapp Group yang diberikan kepada 15 orang guru sebagai peserta pelatihan.

2. Pelatihan

Pada kegiatan ini bertujuan untuk memberikan pengetahuan dan pelatihan bagaimana memanfaatkan layanan Google Classroom khususnya bagi para guru-guru SMPIT Insan Rabbani melalui pemberian materi-materi mengenai layanan-layanan Google Classroom yang disertai dengan memberikan contoh secara langsung baik dalam pembuatan kelas, peng-upload-an materi, pemberian kuis dan tugas, forum diskusi serta penyimpanan datadata pembelajaran dengan menggunakan Google Drive. Kegiatan pelatihan ini dilaksanakan secara virtual dengan menggunakan aplikasi Google Meets dan Zoom.

3. Simulasi Pelatihan

Simulasi pelatihan pengenalan dan pemanfaatan layanan Google Classroom sehingga para guru-guru SMPIT Insan Rabbani peserta pelatihan dapat memahami dan mengerti pemanfaatan layanan berbasis Google Classroom dan dapat mengimplementasikannya, pada simulasi ini para peserta juga diberikan penugasan. Sehingga layanan Google Classroom ini dapat menjadi salah satu pilihan media pembelajaran daring saat pandemi ini.

\section{HASIL DAN PEMBAHASAN}

Hasil kegiatan pelatihan pengenalan dan pemanfaatan layanan Google Classroom pada pembelajaran daring dihadiri oleh 15 orang guru 
Pandemi COVID 19 di SMPIT Insan Rabbani - Diah Aryani, Malabay, Hani Dewi Ariessanti, Syahrizal Dwi Putra

DOI : https://doi.org/10.31004/abdidas.v1i5.67

sebagai peserta pelatihan secara virtual melalui aplikasi Google Meets dan Zoom pada bulan Juni 2020. Kegiatan abdimas ini menggunakan 3 tahapan proses yaitu pendaftaran peserta, pelaksanaan kegiatan pelatihan dan penugasan praktik.

\section{Pendaftaran Peserta}

Kegiatan abdimas ini dilaksanakan pada masa pandemi COVID 19 sehingga bertujuan untuk memberikan pelatihan pada guru-guru SMPIT Insan Rabbani dalam menambah pengetahuan dan kemampuan dalam pemanfataan salah satu aplikasi pembelajaran daring yaitu layanan Google Classroom sehingga peserta hanya terbatas pada guru-guru SMPIT Insan Rabbani.

Peserta dapat bergabung pada kegiatan pelatihan dengan pemberian materi pelatihan melalui presentasi/ceramah, diskusi dan tanya jawab untuk pelatihan pertama menggunakan aplikasi zoom.

Sedangkan untuk pelatihan kedua, dimana kegiatan abdimas ini merupakan simulasi bagaimana memanfaatkan layanan Google Classroom dan setiap peserta diwajibnya memiliki akun Gmail. Untuk dapat bergabung peserta dapat menggunakan aplikasi Google Meets dengan link: https://meet.google.com/iep-xmqy-njy.

Berikut data peserta yang sudah memiliki akun Gmail pada pelatihan pertama, sisanya sudah memiliki akun email namun bukan gmail. Penggunaan Google Classroom tidak memerlukan proses instalansi yang rumit dan jika seorang administrator melakukan setup account google maka user dapat menggunakan layanan Google
Classroom dengan akun Gmail masing-masing (Nurfalah,2019).

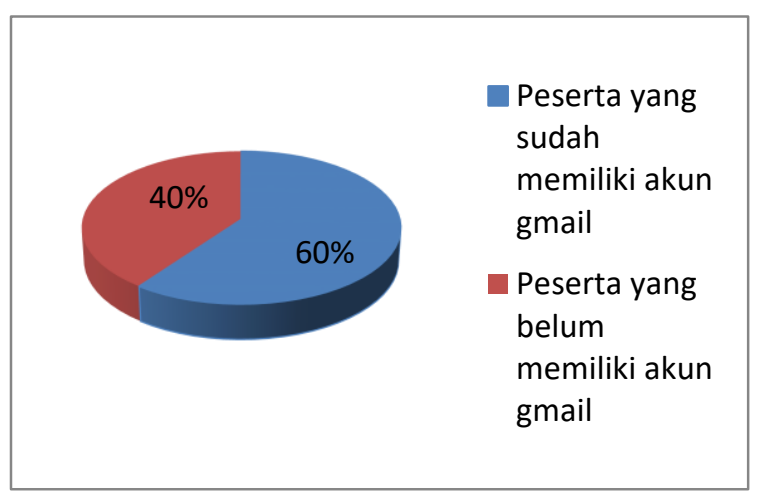

Gambar 1. Data Peserta yang Memiliki Akun Gmail

\section{Pelatihan}

Kegiatan abdimas ini dilaksanakan dengan dua pelatihan, dimana pelatihan pertama melalui pemaparan materi dengan presentasi, diskusi dan tanya jawab sedangkan pelatihan kedua melalui simulasi praktik secara langsung dan menyaksikan video. Beberapa peserta ada yang belum mengetahui Google Classroom, ada juga yang hanya mendengar dan yang sudah pernah mencoba. Data pengetahuan peserta tentang Google Classroom dijelaskan pada gambar berikut.

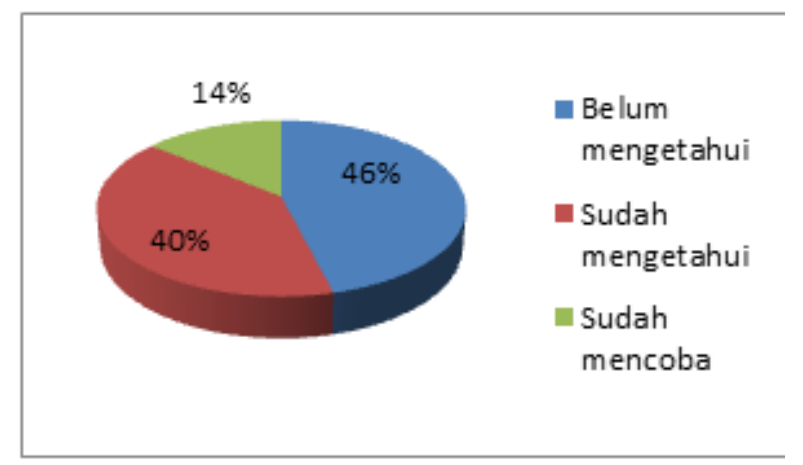

Gambar 2. Distiribusi Pengetahuan Peserta 
Pandemi COVID 19 di SMPIT Insan Rabbani - Diah Aryani, Malabay, Hani Dewi Ariessanti, Syahrizal Dwi Putra

DOI : https://doi.org/10.31004/abdidas.v1i5.67

Para guru peserta pelatihan sebelumnya wajib memiliki akun Gmail sebagai kunci agar bisa memanfaatkan fasilitas yang ada di Google khususnya untuk layanan Google Classroom dan Google Drive, laptop yang terhubung langsung dengan internet, pemberian materi pelatihan melalui email, serta tanya jawab langsung pada saat pelatihan maupun melalui fasilitas chat ada pada aplikasi Zoom dan Google Meets.

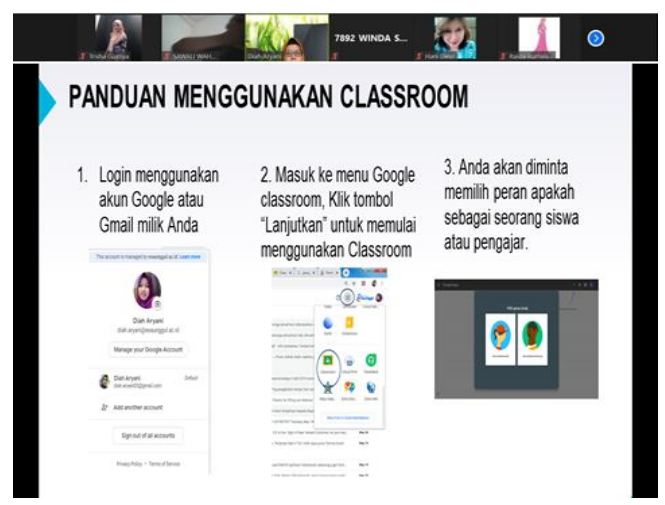

Gambar 3. Pelaksanaan Pelatihan Virtual

Selama pelaksansaan pemaparan materi yang dilakukan secara virtual juga terjadi diskusi dimana dari diskusi tersebut kesulitan dari para guru dalam menerapkan layanan Google terutama saat pengunduhan nilai tugas dan kuis baik berbentuk essai maupun opsional, serta belum terbiasanya para guru dalam pemanfaatan layanan penyimpanan Cloud yang dimiliki Google yaitu Google Drive. Untuk mengatasi hal tersebut maka penyajian pelatihan ini juga disetai dengan simulasi praktik baik dengan contoh maupun pemberian materi berupa video.

\section{Simulasi Praktik}

Kegiatan abdimas setelah pelaksanaan pelatihan dilanjutkan dengan simulasi praktik, dimana simulasi ini langsung dipandu oleh trainer dan juga peserta diberikan materi berupa video praktik yang guna supaya peserta dapat melanjutkan mempelajari diluar waktu pelatihan. Para peserta pelatihan juga diberikan tugas praktik yang dikerjakan selama satu minggu untuk seluruh peserta. Berdasarkan data hasil penugasan yang dikerjakan oleh para peserta pelatihan, maka hasil analisi penugasan terdapat pada tabel berikut.

Tabel 1. Analisa Hasil Penugasan

\begin{tabular}{|c|c|}
\hline Bentuk Tugas & Analisis Hasil Tugas \\
\hline Membuat Kelas & $\begin{array}{l}\text { Seluruh peserta dapat membuat } \\
\text { kelas didalam Google Classroom }\end{array}$ \\
\hline $\begin{array}{l}\text { Mengundang } \\
\text { Siswa }\end{array}$ & $\begin{array}{l}\text { Kendala untuk mengundang } \\
\text { siswa, belum seluruh siswa } \\
\text { memiliki akun Gmail }\end{array}$ \\
\hline $\begin{array}{l}\text { Mengupload materi } \\
\text { dalam bentuk file, } \\
\text { link dan video }\end{array}$ & $\begin{array}{lll}\text { Seluruh } & \text { peserta } & \text { dapat } \\
\text { mengupload } & \text { materi pada kelas } \\
\text { yang sudah dibuat di Google } \\
\text { Classroom }\end{array}$ \\
\hline $\begin{array}{lr}\text { Menyiapkan } & \text { tugas } \\
\text { dan } & \text { Sistem } \\
\text { Penilaian } & \end{array}$ & $\begin{array}{l}\text { Peserta dapat menyiapkan tugas } \\
\text { namun terdapat menyiapkan } \\
\text { sistem penilian sebanyak } 20 \%\end{array}$ \\
\hline $\begin{array}{l}\text { Membuat forum } \\
\text { diskusi }\end{array}$ & $\begin{array}{l}\text { Seluruh peserta dapat membuat } \\
\text { forum diskusi, namun } 30 \% \\
\text { peserta hanya online pada jam } \\
\text { kerja }\end{array}$ \\
\hline $\begin{array}{l}\text { Menyimpan materi } \\
\text { bahan ajar didalam } \\
\text { Google Drive }\end{array}$ & $\begin{array}{l}\text { Seluruh peserta mampu } \\
\text { melakukan penyimpanan materi } \\
\text { bahan ajar dan data kelas lainnya } \\
\text { dalam Google Drive }\end{array}$ \\
\hline
\end{tabular}

\section{SIMPULAN}

Kegiatan abdimas ini secara keseluruhan dapat berjalan dengan lancar dan baik serta respon yang antusias dari peserta pelatihan, dengan jumlah peserta 15 guru SMPIT Insan Rabbani. Berdasarkan hasil analisis dari kegiatan pelatihan dan penugasan yang diberikan saat pelatihan dapat diketahui sejak awal pelatihan terdapat $40 \%$ perserta yang belum memiliki akun gmail, $46 \%$ belum mengetahui layanan Google Classroom. 
Setelah peserta mengerjakan penugasan yang diberikan maka dapat dianalisis semua peserta mampu membuat kelas baru, mengupload bahan ajar dalam bentuk file, link dan video, menyimpan bahan ajar dalam layanan Google Drive, mengundang siswa untuk bergabung di kelas, sebanyak $20 \%$ peserta belum dapat menyiapkan sistem penilaian, peserta dapat melakukan forum diskusi pada jam kerja sebanyak 30\% hal ini dikarenakan fasillitas internet yang terbatas. Selain itu kendala selama pelatihan antara lain data belum seluruh siswa memiliki akun Gmail sehingga ini menjadi bagian tugas para guru untuk mengarahkan siswanya membuat akun Gmail.

Sehingga dengan dilaksanakan kegiatan abdimas melalui pelatihan ini terjadi transfer knowledge tentang pemahaman dan kemampuan dalam memanfaatkan layanan Google Classroom yang merupakan salah satu aplikasi pendukung pembelajaran daring. Sehingga layanan Google Classroom dapat menjadi salah satu alternatif bagi para guru SMPIT Insan Rabbani dalam memilih aplikasi pendukung pembelajaran daring selama masa pandemi ini dan kegiatan pembelajaran dapat berjalan dengan baik.

\section{DAFTAR PUSTAKA}

Maharani, N., \& Kartini, K. S. (2019). Penggunaan google classroom sebagai pengembangan kelas virtual dalam keterampilan pemecahan masalah topik kinematika pada mahasiswa jurusan sistem komputer. PENDIPA Journal of Science Education, 3(3), 167-173. https://doi.org/10.33369/pendipa.3.3.167-173

Nurfalah, E. (2019). Optimalisasi E-Learning berbasis Virtual Class dengan Google Classroom sebagai Media Pembelajaran
Fisika. Physics Education Research Journal, l(1), 46. https://doi.org/10.21580/perj.2019.1.1.3977

Rahmawati, D., \& Anindhita, W. (2016). Potensi Media Daring Menciptakan Komunitas Informasi. Jurnal Bakrie, 730-736.

Sabran, \& Sabara, E. (2019). Keefektifan Google Classroom sebagai media pembelajaran. PROSIDING SEMINAR NASIONAL LEMBAGA PENELITIAN UNIVERSITAS NEGERI Makasar, 122-125. https://webcache.googleusercontent.com/sear ch?q=cache:SS_jKM_r2TAJ:https://ojs.unm. ac.id/semnaslemlit/article/download/8256/47 $67+\& \mathrm{~cd}=2 \& \mathrm{hl}=\mathrm{id} \& \mathrm{ct}=\mathrm{clnk} \& \mathrm{gl}=\mathrm{id}$ 